\title{
Analisis Ketercapaian Implementasi Rencana Pengembangan Sekolah Standar Proses Pendidikan di SMK Mandala Kabupaten Bogor
}

\author{
Wawan Karsiwan, Agi Juandi, Leonaldi, Rizqika Afthortu Wijaya, Dinda Amelia \\ STKIP Muhammadiyah Bogor \\ e-mail:wawankarsiwan@gmail.com
}

\begin{abstract}
This research aims to determine the achievement of the implementation of school development plans on the standard of education process in SMK Mandala Bogor Regency. Where the standard of the process is a provision that must be implemented by teachers in ensuring the implementation of effective learning. This study uses a quantitative approach approach with descriptive methods supported by data collection tools in the form of questionnaires in the form of google forms in order to achieve process standards with a focus on three main indicators, namely: Learning Planning, Learning Implementation, and Evaluation of learning and poured in the form of 25 questions. Meanwbile, the research samples targeted by this study were teachers of SMK Mandala Bogor Regency which amounted to 27 teachers. The results showed that in general the achievement of The Education Process Standard reached $71.33 \%$, and specifically the achievement on the Learning Planning indicator by $71.53 \%$, the Learning Implementation Indicator by $71.4 \%$, and the last indicator of learning evaluation by $71.05 \%$. From the achievement, it can be interpreted that the teachers at SMK Mandala have run the standard of education process in accordance with the provisions of the applicable process standards well and continuously, and the teachers have carried out the principles of learning as stipulated in the School Development Plan.
\end{abstract}

Keywords: school development plan, education process standards, teachers

\begin{abstract}
ABSTRAK
Penelitian ini bertujuan untuk mengetahui ketercapaian implementasi rencana pengembangan sekolah pada standar proses Pendidikan di SMK Mandala Kabupaten Bogor. Dimana standar proses merupakan ketentuan yang harus dilaksanakan oleh guru dalam menjamin pelaksanaan pembelajaran yang efektif. Penelitian ini menggunakan pendekatan pendekatan kuantitatif dengan metode deskriptif yang didukung dengan alat pengumpulan data berupa angket dalam bentuk google form dalam megukur ketercapaian standar proses dengan fokus pada tiga indikator utama, yaitu: Perencanaan Pembelajaran, Pelaksanaan Pembelajaran, dan Evaluasi pembelajaran dan dituangkan dalam bentuk 25 pertanyaan. Sementara, sampel penelitian yang menjadi sasaran penelitian ini adalah guru-guru SMK Mandala Kabupaten Bogor yang berjumlah sebanyak 27 orang guru. Hasil penelitian menunjukan bahwa secara umum ketercapaian Standar Proses Pendidikan mencapai $71.33 \%$, dan secara spesifik pencapaian pada indicator Perencanaan Pembelajaran sebesar 71.53\%, Indikator Pelaksanaan Pembelajaran sebesar 71.4\%, dan terakhir indikator evaluasi pembelajaran sebesar $71.05 \%$. Dari pencapain tersebut, dapat dimaknai bahwa guru-guru di SMK Mandala telah menjalankan standar proses pendidikan sesuai dengan ketentuan standar proses yang berlaku dengan baik dan berkesinambungan, serta guru-guru telah menjalankan prinsip pembelajaran sesuai yang ditetapkan dalam Rencana Pengembangan Sekolah.
\end{abstract}

Kata Kunci: rencana pengembangan sekolah, standar proses pendidikan, guru

Submitted Apr 02, 2021 | Revised Apr 22, 2021 | Accepted Apr 30, 2021

\section{Pendahuluan}

Rencana pengembangan sekolah merupakan perencanaan komprehensif yang harus dibuat oleh Satuan Pendidikan. Di mana dalam rencana pengembangan sekolah terdapat berbagai target pencapaian satuan Pendidikan yang dirumuskan ke dalam delapan standar nasional Pendidikan. Salah satu standar nasional Pendidikan yang sangat penting dan berhubungan langsung dengan kualitas pembelajaran adalah standar proses. Standar proses merupakan variable yang perlu diperhatikan untuk dapat menghasilkan output yang memiliki kualitas kompetitif. Maka dari itu sangat diperlukan terjadinya suatu proses pendidikan atau pembelajaran yang optimal (Handayani, 2016; Puspitasari, 2018; Nurhayati, et al., 2020). Standar proses pembelajaran perlu dilakukan perbaikan dan peningkatan secara berkelanjutan karena perannya yang sangat strategis dalam menjamin mutu pendidikan 
(Damanik, 2015; Alawiyah, 2017; Anwar, 2018). Standar proses ini merupakan ketentuan-ketentuan yang harus dilaksanakan oleh guru dalam melaksnakan proses pembelajaran, Sehingga diharapkan proses pembelajaran dapat dilaksnakan bermutu dan mampu mengantarkan peserta didik mencapat perkembangan yang diharapkan baik pengetahuan, keterampilan dan kepribadian.

Dalam pembangunan Pendidikan di Indonesia, visi pendidikan nasional adalah terwujudnya sistem pendidikan sebagai pranata sosial yang kuat dan berwibawa untuk memberdayakan semua warga negara Indonesia berkembang menjadi manusia yang berkualitas sehingga mampu dan proaktif menjawab tantangan jaman yang selalu berubah.

Dalam Undang-undang nomor 20 tahun 2003 tentang Sistem Pendidikan Nasional, pasal 1 angka 1 yang menyatakan bahwa pendidikan adalah usaha sadar dan terencana untuk mewujudkan suasana belajar dan proses pembelajaran agar peserta didik secara aktif mengembangkan potensi dirinya untuk memiliki kekuatan spiritual keagamaan, pengendalian diri, kepribadian, kecerdasan, akhlak mulia, serta keterampilan yang diperlukan dirinya, masyarakat, bangsa dan negara. Maka untuk mewujudkannya, diperlukan suatu kebijakan oleh pemerintah yang merupakan langkah nyata terhadap keberhasilan pendidikan di Indonesia. Mengingat perkembangan jaman yang semakin maju dan pesat, sehingga diperlukan suatu terobosan dalam bidang pendidikan agar tujuan yang telah ditetapkan dapat tercapai dengan baik yaitu berupa pembaharuan kurikulum pendidikan.

Dengan kata lain, untuk mewujudkan tujuan dari pendidikan diperlukan suatu standar yang digunakan sebagai pedoman pelaksanaan pendidikan yang bermutu. Mengacu pada peraturan pemerintah (PP No. 32 Tahun 2013 perubahan PP No.19 Tahun 2005) mengenai standar pendidikan nasional. Salah satu dari delapan standar pendidikan nasional adalah standar proses pendidikan yang memiliki fungsi sebagai pengendali proses pendidikan. Standar proses ini dikembangkan sejak tahun 2006 oleh Badan Standar Nasional Pendidikan dan pada tahun 2007 diterbitkan menjadi Peraturan Menteri Pendidikan Nasional Republik Indonesia, yaitu Permendiknas RI No. 41 Tahun 2007. Pada tahun 2013 pemerintah memberlakukan kurikulum 2013 secara bertahap, standar proses satuan pendidikan juga mengalami penyempurnaan yang dituangkan dalam Peraturan Menteri Pendidikan dan Kebudayaan Republik Indonesia Nomor 65 Tahun 2013 tentang Standar Proses Satuan Pendidikan Dasar dan Menengah yang dituangkan dalam Permendikbud Nomor 22 Tahun 2016.

Sementara itu, berdasarkan penelitian yang dilakukan oleh (Astrada; Amay Suherman, 2014) bahwa guru-guru dalam melaksanakan pembelajaran baik pada tahapan perencanaan, pelaksanaan dan evalausi pembelajaran belum sepenuhnya mengacu pada ketentuan standar proses yang berlaku. Guru selama ini, memang sangat lemah dalam mengembangkan proses pembelajaran yang, apa lagi untuk sesuai standar proses pendidikan. Proses pembelajaran di kelas, kebanyakan dilaksanakan sesuai dengan selera dan kemampuan guru yang mengajar (Nurhasni, 2017). Oleh karena itu, penting untuk mengoptimalisasikan guru-guru dalam melaksanakan pembelajaran dengan berpedoman pada standar proses Pendidikan, sehingga diharapkan Pendidikan bermutu dapat dicapai (Zaini, 2013). Dari beberapa hasil penelitian tersebut, dapat disimpulkan bahwa standar proses pendidikan merupakan standar minimal yang hendaknya dipenuhi oleh setiap satuan pendidik agar pembelajaran berjalan dengan baik dan teratur, dalam standar ini peran guru sebagai salah satu pelaksana standar proses pendidikan harus memberikan pengaruh besar terhadap peserta didiknya.

Proses pembelajaran yang baik terjalin dari guru yang menjalankan standar proses pendidikan dengan baik. Selain itu, agar pembelajaran berjalan dengan baik, sebaiknya setiap satuan pendidikan dan para pendidiknya harus berusaha memenuhi persyaratan pembelajaran sesuai dengan tuntutan standar proses pendidikan. Berdasarkan penjelasan di atas, penelitian ini bertujuan untuk mengetahui ketercapaian implementasi rencana pengembangan sekolah pada standar proses Pendidikan di SMK Mandala Kabupaten Bogor. Di mana standar proses merupakan ketentuan yang harus dilaksanakan oleh guru dalam menjamin pelaksanaan pembelajaran yang efektif. 


\section{Metode Penelitian}

Penelitian ini menggunakan pendekatan Kuantitatif dengan metode deskriptif. dimana pendekatan kuantitatif menekankan analisisnya pada data-data numerical yang diolah dengan metode statiska (Azwar, 2012). Penelitian dengan pendekatan kuantitatif bertujuan menggambarkan secara sistematik dan akurat fakta dan karakteristik mengenai populasi atau bidang tertentu. Sampel yang digunakan untuk penelitian ini adalah 30 guru mata pelajaran di SMK Mandala. Alat pengumpulan data yang digunakan berupa angket yang disajikan secara online melalui media Google Form yang terdiri atas 25 pertanyaan penelitian meliputi 3 indikator utama pada Standar Proses Pendidikan yaitu Perencanaan, Pelaksanaan dan Penilaian Pembelajaran. Analisis data yang digunakan untuk mengetahui tingkat Analisis Ketercapaian Implementasi RPS Standar Proses Pendidikan di SMK Mandala menggunakan analisis deskriptif kuantitatif.

\section{Hasil dan Pembahasan}

Data yang diamati dalam Penelitian Analisis Ketercapaian Implementasi Rencana Pengembangan Sekolah pada Standar Proses Pendidikan di Sekolah Menengah Kejuruan Mandala ini didapat dari data yang terkumpul dari jawaban responden penelitian. Untuk menganalisa implementasi Standar Proses Pendidikan di SMK Mandala, disajikan beberapa pernyataan yang terkait dengan kesiapan guru dalam proses pembelajaran. Alat pengumpulan data yang digunakan adalah angket dengan disajikan secara online melalui media Google Form yang terdiri atas 25 item pernyataan penelitian meliputi 3 indikator utama dalam Standar Proses Pendidikan yaitu indikator Perencanaan pembelajaran, indikator Pelaksanaan pembelajaran dan indikator Penilaian Pembelajaran. Para guru diminta untuk menjawab setiap pernyataan tersebut sesuai dengan pendapat atau sesuai dengan kondisi yang sesungguhnya dalam pelaksanaan proses pembelajaran di sekolah. dalam menjawab setiap pernyataan itu, para guru dapat memilih salah satu alternatif jawaban yang telah disediakan, yaitu: Sangat Sesuai (SS), Sesuai (S), Kurang Sesuai (KS), dan Tidak Sesuai (TS). Guru menjawab pertanyaan berbentuk angket yang terdiri atas 25 pernyataan dimana dalam masing-masing pernyataan terdapat 4 opsi jawaban dan responden harus memilih salah satu alternatif jawaban yang sesuai.

Pertanyaan disusun kedalam puluh lima pernyataan yang terdiri tiga indikator utama dalam pengimplementasian Rencana Pengembangan Sekolah Standar Pendidikan. terdiri atas: 1) Indikator Perencanaan Pembelajaran; yaitu pada pernyataan No. 1 sampai No. 9, 2) Indikator Pelaksanaan Pembelajaran; yaitu pada pernyataan No. 10 sampai No. 18, dan 3) Indikator Penilaian Pembelajaran; yaitu pada pernyataan No. 19 sampai No. 25. Dalam menganalisis data, menurut Sugiono, (2012) langkah utama yang harus dilakukan adalah menentukan skor dari setiap jawaban yang diberikan. Maka menetentuan penskoran pada masing-masing pernyataan berdasarkan kategori jawaban sebagai mana tabel 1:

Tabel 1. Ketentuan skor pada skala jawaban

\begin{tabular}{cl}
\hline Skala Jawaban & Skor \\
\hline Tidak Sesuai Standar & 1 \\
Kurang Sesuai Standar & 2 \\
Sesuai Standar & 3 \\
Sangat Sesuai Standar & 4 \\
\hline
\end{tabular}

Sampel/responden yang ditentukan sebelumnya berjumlah 30 responden, namun pada realisasi berhasil mendapatkan data dari 27 responden, adapun data hasil penelitian disajikan dalam bentuk grafik presentase yang digambarkan berdasarkan masing-masing indikator sebagai berikut: 


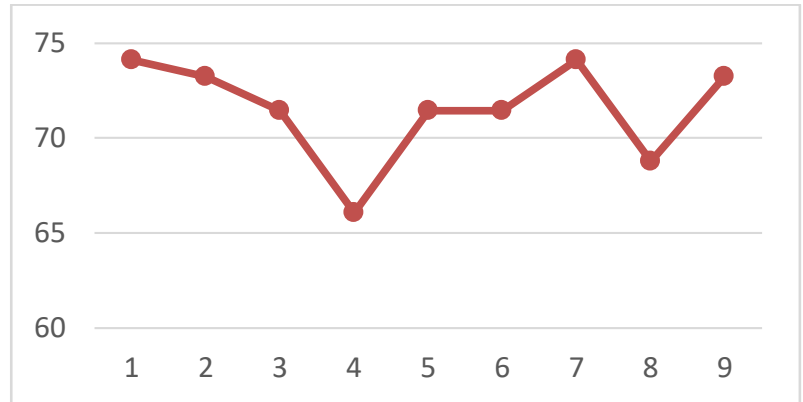

Gambar 1. Hasil Ketercapaian Perencanaan Pembelajaran

Pada Gambar 1 menunjukan persentase indikator perencanan pembelajaran dalam penerapan RPS Standar Pendidikan di SMK Mandala yang terdiri atas 9 pernyataan. Ketercapaian pada indikator perencanaan proses pembelajaran dalam penerapan RPS Standar Proses Pendidikan di SMK Mandala sebesar $71,53 \%$. Dari hasil data yang diperoleh tersebut, peneliti dapat menarik kesimpulan bahwa dalam indikator perencanaan pembelajaran di SMK Mandala dikategorikan sesuai dengan standar proses pendidikan, meskipun hasilnya belum mencapai pada kategori sangat sesuai dengan standar.

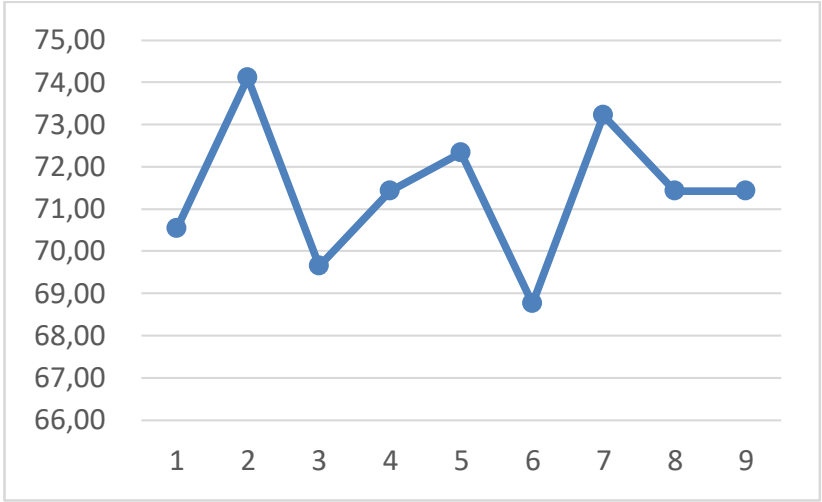

Gambar 2. Hasil Ketercapaian Pelaksanaan Pembelajaran

Pada gambar 2 menunjukan persentase indikator 2 mengenai proses pelaksanaan pembelajaran dalam penerapan Standar Proses Pendidikan di SMK Mandala yang terdiri atas 9 pernyataan, dengan ketercapaian sebesar $71,43 \%$.

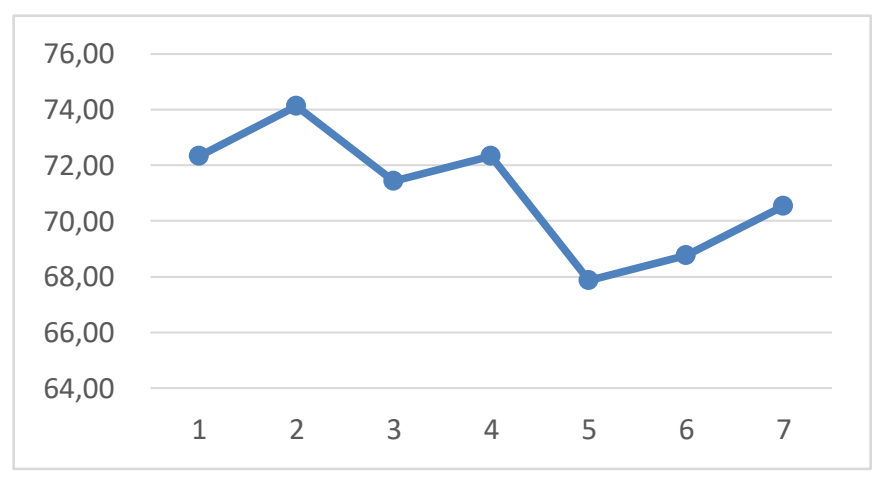

Gambar 3. Ketercapaian Penilaian Pembelajaran

Selanjutnya, pada gambar 3 menunjukan persentase indikator evaluasi pembelajaran dalam penerapan Standar Proses Pendidikan di SMK Mandala, terdiri atas tujuh pernyataan. Ketercapaian 
dalam indikator penilaian pembelajaran di SMK Mandala sebesar 71,05\%. Hasil data ini didapat dari data para responden penelitian, sehingga peneliti dapat menarik kesimpulan data untuk ketercapaian pengimplementasian Standar pendidikan pada indikator evaluasi atau penilaian pembelajaran di SMK Mandala dikategorikan sesuai dengan standar.

Hasil data pada indikator ini hanya mencapai proporsi sebanyak 71,05\% yang memiliki selisih besar 28,95\% dengan proporsi yang diharapkan. Hasil analisis data responden untuk indikator penilaian pembelajaran menunjukan bahwa kurangnya ketercapaian pada indikator ini disebabkan karena kurangnya pemahaman guru terhadap komponen indikator penilaian pembelajaran, seperti dalam mengembangkan penilaian autentik, ulangan harian, UTS dan UAS. terdata sebagian guru yang pada pelaksnaannya kurang sesuai dengan standar, tentu hal itu juga akan berpengaruh pada proses menindak lanjuti penilaian baik dengan melaksanakan remedial maupun pengayaan.

Namun dalam hal menilai pengetahuan, sikap dan keterampilan peserta didik, serta penetapan nilai KKM untuk pembelajaran bisa dikatakan bahwa guru di SMK Mandala sudah bisa melaksanakan sesuai dengan standar penilaian, Serta hasil data menunjukan bahwa sebagian banyak guru di SMK Mandala dalam menilai pencapaian belajar siswa, penilaian dilakukan berdasarkan indikator pencapaian kompetensi pada standar proses pendidikan.

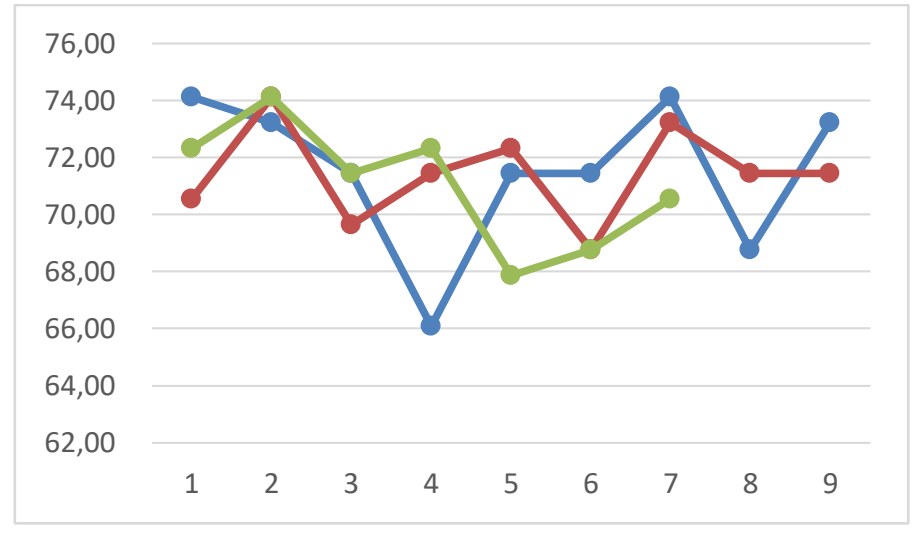

Gambar 4. Ketercapaian Standar Proses Pendidikan

Maka jika hasil data rata-rata tingkat ketercapaian pada standar proses sebesar 71,33\%. Pada gambar 4 menunjukan hasil presentase keseluruhan dari tiga indikator standar proses pendidikan di SMK Mandala, tiga indikator tersebut meliputi; indikator perencanaan, indikator pelaksanaan dan indikator penilaian dalam pembelajaran. Maka hasil ini dapat disimpulkan bahwa secara umum guru-guru di SMK Mandala telah menjalankan standar proses pendidikan dengan baik dan berkesinambungan, serta prinsip pembelajaran sesuai dengan RPS yang telah dibuat. Hasil lain menunjukan guru telah memiliki kesiapan mengajar yang cukup baik berdasarkan tiga indikator utama pada standar proses pendidikan yang terdiri atas perencanaan pembelajaran, pelaksanaan pembelajaran dan penilaian pembelajaran.

Berdasarkan Permendiknas Nomor 41 Tahun 2007, standar proses adalah standar nasional pendidikan yang berkaitan dengan pelaksanaan pembelajaran pada satuan pendidikan untuk mencapai kompetensi lulusan. Standar proses ini mencakup: perencanaan proses pembelajaran, pelaksanaan proses pembelajaran, penilaian hasil pembelajaran, dan pengawasan proses pembelajaran. Perencanaan pembelajaran mengenai silabus, dan rencana pelaksanaan pembelajaran (RPP). Pelaksanaan proses pembelajaran mengenai persyaratan pelaksanaan (rombongan belajar, beban kerja minimal guru, buku teks pelajaran, pengelolaan kelas), pelaksanaan pembelajaran yaitu mengenai kegiatan pendahuluan, kegiatan inti (eksplorasi, elaborasi, dan konfirmasi) dan kegiatan penutup. Penilaian hasil pembelajaran dilakukan oleh guru dengan pengamatan langsung atau 
dengan melakukan test maupun non-test. Lalu yang terakhir pengawasan proses pembelajaran mengenai pemantauan, supervisi, evaluasi, pelaporan, dan tindak lanjut.

Standar proses merupakan standar yang penting dalam menentukan keberhasilan suatu proses pembelajaran, faktanya dalam standar ini sudah dirumuskan bahwa ketika guru sudah merencanakan program pembelajaran yang sesuai dengan kurikulum yang ada, maka tingkat ketercapaian keberhasilan pada proses pembelajaran dapat dikatakan sesuai dengan standar yang berlaku. Hal tersebut menjadi penyebab diselenggarakannya analisis pada standar proses di salah satu sekolah menengah kejuruan swasta yang berada diwilayah Kecamatan Leuwiliang Kabupaten Bogor. SMK Mandala dipilih sebagai tempat pengumpulan data yang dibutuhkan untuk analisis standar proses disekolah tersebut. Adapun rumusan masalah dalam penelitian ini adalah: untuk menganalsis bagaimana ketercapaian impelementasi Rencana Pengembangan Sekolah Standar Proses Pendidikan di SMK Mandala.

Hasil penelitian yang kami peroleh dari satuan pendidikan di sekolah menengah kejuruan (SMK Mandala) yaitu, pertama pada proses perencanaan pembelajaran. Proses perencanaan pembelajaran merupakan suatu proses kegiatan yang merumuskan tujuan-tujuan apa yang ingin dicapai oleh suatu kegiatan pembelajaran. Perencanaan ini dibuat agar kegiatan pembelajaran yang telah kita buat dapat dilaksanakan dengan baik dan berjalan dengan optimal terutama pada satuan pendidikan di sekolah menengah kejuruan yang mana pembelajarannya lebih terpusat pada pengembangan kemampuan siswa. Sehingga perlu adanya perencanaan yang matang dalam melakukan proses pembelajaran. Pada proses ini data yang kami peroleh dari hasil proses perencanaan pembelajaran tercapai hanya 71,53 . Hal ini dikarenakan oleh kesadaran guru dalam merumuskan dan mengatur proses pembelajaran yang akan dilakukan seperti mengatur RPP, strategi pembelajaran, model/metode pembelajaran yang cocok digunakan pada proses pembelajaran di sekolah menengah kejuruan dan lain sebagainya. Sehingga dalam proses perencanaan pembelajaran ini dapat dikatakan cukup baik atau memenuhi standar yang telah ditetapkan.

Kedua, pelaksanaan pembelajaran. Pelaksanaan pembelajaran ini digunakan untuk melakukan proses pembelajaran yang telah diatur dengan sedemikian rupa. Pada proses pelaksanaan pembelajaran hasil hanya didapat $71,43 \%$. Pada tahap proses pelaksanaan pembelajaran data yang diperoleh bisa dikategorikan memenuhi/sesuai standar. Hal ini disebabkan karena guru disekolah tersebut telah melakukan proses pembelajarannya dengan baik sesuai dengan rencana yang dibuat sebelumnya (RPP). Selain itu guru di SMK Mandala juga mempunyai metode-metode pembelajaran yang bervariasi dan berinovasi dalam melakukan pembelajarannya sesuai dengan mata pelajaran yang diampu. Jadi, dalam proses pelaksanaan pembelajaran ini dapat dikatan sesuai/memenuhi dengan standar yang telah ditetapkan.

Terakhir, pada indikator evaluasi pembelajaran. Evaluasi pembelajaran itu sendiri merupakan suatu proses menentukan tingkat pencapaian tujuan pembela jaran yang telah ditentukan sebelumnya melalui cara yang sistematis. Yang menjadi kegiatan utama dalam sebuah evaluasi pembelajaran yaitu pengukuran dan penilaian. Fungsi evaluasi pembelajaran ini sebagai acuan untuk mengetahui capaian hasil belajar siswa. Adanya evaluasi ini dapat meningkatkan efektivitas pembelajaran di kelas, dapat membantu kebutuhan belajar peserta didik, mengetahui Kendala yang dihadi peserta didik, serta menyediakan data yang menjadi tolak ukur dalam pengambilan keputusan bagi pembelajaran kedepannya. Hasil yang diperoleh sebesar $71,05 \%$ yang memiliki selisih sebesar 28,95\% dengan proporsi yang diharapkan.

Maka secara keseluruhan ketercapaian implementasi standar proses Pendidikan sebesar 71,33\%. Hasil ini bisa dikatakan cukup baik dan cukup memenuhi standar pendidikan di satuan pendidikan pada SMK Mandala. Hasil ini juga dapat dikembangkan lagi untuk meningkatkan standar proses disekolah tersebut agar standar yang diharapkan dapat sesuai dan tercapai dengan optimal. 


\section{Kesimpulan}

Dunia pendidikan di Indonesia bukanlah hal yang sederhana. Perlu adanya keseriusan dari berbagai pihak seperti pemerintah dan masyarakat untuk mewujudkan tujuan pendidikan nasional yang telah dibuat/ditetapkan sebelumnya. Ada beberapa standar yang perlu diperhatikan dalam proses pendidikan nasional yang salah satunya yaitu standar proses pendidikan. Standar proses adalah kriteria mengenai pelaksanaan pembelajaran pada satuan pendidikan untuk mencapai Standar Kompetensi Lulusan. Proses pembelajaran pada satuan pendidikan dilaksanakan interaktif, inspiratif, menyenangkan, menantang, memotivasi peserta didik, untuk berpartisipasi aktif, serta memberikan ruang yang cukup bagi prakarsa, kreativitas, dan kemandirian sesuai bakat, minat, dan perkembangan fisik, serta psikologis peserta didik. Untuk itu setiap satuan pendidikan melakukan perencanaan pembelajaran, pelaksanaan pembelajaran serta penilaian atau evaluasi pembelajaran untuk meningkatkan efisiensi dan efektifitas ketercapaian kompetensi lulusan. Yang mana salah satu faktor utama dalam sebuah standar proses pendidikan adalah proses pembelajaran disekolah. Dalam hal ini proses pembelajaran merupakan salah satu inti dalam sebuah pendidikan. Dalam hal inilah yang menjadi ujung tombak dalam proses pembelajaran adalah pendidik atau guru. Maka dari itu seorang pendidik atau guru harus mempersiapkan segalanya untuk keberlangsungan pembelajaran yang akan mereka lakukan disatuan pendidikan.

Satuan pendidikan di sekolah menengah kejuruan (SMK) Mandala merupakan salah satu sekolah yang termasuk unggulan. Karena sekolah ini menerapkan standar pendidikan dengan baik di sekolahnya yang salah satunya yaitu standar proses. Standar proses disekolah tersebut terbilang memenuhi standar yang telah ditetapkan. Hal ini bisa dilihat dari hasil penelitian kami pada sekolah tersebut yang mana hasil penelitian standar proses pendidikan di SMK Mandala mencapai 71,33\% artinya cukup baik dan sesuai dengan standar.

\section{Daftar Pustaka}

Alawiyah, F. (2017). Standar Nasional Pendidikan Dasar Dan Menengah. Aspirasi: Jurnal Masalahmasalah Sosial, 8(1), 81-92. doi:https://doi.org/10.46807/aspirasi.v8i1.1256

Anwar, K. (2018). Peran sistem penjaminan mutu pendidikan dalam meningkatkan mutu pendidikan di madrasah. TA'DIBUNA: Jurnal Pendidikan Agama Islam, 1(1), 41-56.

Astrada; Amay Suherman, Y. (2014). 25 Studi Pelaksanaan Standar Proses Di Sekolah Menengah Kejuruan. Journal of Mechanical Engineering Education, 1(1), 25-34.

Azwar, S. (2012). Reliabilitas dan Validitas. Pustaka Pelajar.

Damanik, J. (2015). Upaya dan Strategi Pemenuhan Standar nasional Pendidikan. Jurnal Dinamika Pendidikan, 8(3), 151-160.

Depdiknas. (2006). Panduan Penyusunan Rencana Pengembangan Sekolab (RPS). In Departemen Pendidikan Nasionalsional.

Komalasari, K. (2013). Pembelajaran Kontekstul: Konsep dan Aplikasi. Alfabeta.

Handayani, M. (2016). Pencapaian Standar Nasional Pendidikan Berdasarkan Hasil Akreditasi Sma Di Provinsi Dki Jakarta. Jurnal Pendidikan Dan Kebudayaan, 1(2), 179-201. https://doi.org/10.24832/jpnk.v1i2.766

Nurhasni. (2017). Belajar Dan Mengajar Berdasarkan Standar Proses Pendidikan “ Apa Perlunya ?” Jurnal BAPPED A, 3, 53-59.

Nurhayati, S., Redha, L., \& Laksana, L. (2020). Analisis ketercapaian indikator standar proses pada ma addzuriyatus sholihin. Khazanah pendidikan, 14(1). 
Puspitasari, H. (2018). Standar proses pembelajaran sebagai sistem penjaminan mutu internal di sekolah. Muslim heritage, 2(2), 339-368.

Sadiman, A. (1986). Media Pendidikan, pengertian, Pengembangan, dan Pemanfaatannya. Rajawali.

Sugiono. (2012). Metode Penelitian Kuantitatif Kualitatif dan RひB. Alfabeta.

Warsita, B. (2008). Teknologi Pembelajaran: Landasan \& Aplikasinya. Rineka Cipta.

Zaini, A. (2013). Optimalisasi Ketercapaian Standar Proses Pembelajaran untuk Meningkatkan Mutu Pendidikan di SMPN Pamekasan. Jurnal Pendidikan, 1(1), 1-8. https://unimuda.ejournal.id/jurnalpendidikan/article/view/131 